\title{
A Synchronous Tool for Innovation and Improvement of University Communication, Counseling and Tutoring: The WhatsApp Experience
}

\author{
David Pérez-Jorge ${ }^{1 *}$, Fernando Barragán-Medero ${ }^{1}$, Josué Gutiérrez-Barroso ${ }^{2}$, \\ Fátima Castro-León ${ }^{1}$ \\ ${ }^{1}$ Department of Didactics and Educational Research. Faculty of Education, Universidad de La Laguna, La Laguna, SPAIN \\ ${ }^{2}$ Department of Sociology, Universidad de La Laguna, Tenerife, SPAIN
}

Received 10 January 2018 • Revised 17 April $2018 \cdot$ Accepted 17 April 2018

\begin{abstract}
M-learning stands as a different way of learning and the use of WhatsApp appears to be an innovative and effective resource. The objective of this research is to evaluate the effects of the use of this communication tool in the academic monitoring, counseling and tutoring of university students in the Faculty of Education at the University of La Laguna. A control group $(\mathrm{N}=120)$ and an experimental group $(\mathrm{N}=120)$ of first-year students were established (undergraduate students in Childhood Education, Primary Education and Pedagogy) with the aim of knowing the effect of the use of WhatsApp. An ad hoc questionnaire was used to evaluate the development of both those competences related to academic work and performance and those transversal competences through the use of an m-learning tool based on peer tutoring. The results obtained have revealed important improvements as regards those competences related to time efficiency, planning and organization, and those related to active learning, decision making and motivation.
\end{abstract}

Keywords: university counselling, transversal competences, m-learning, WhatsApp

\section{INTRODUCTION}

There are many researches and contributions performed in the field of Educational Guidance and Counselling which emphasize the value of academic tutoring and counselling in Higher Education. The Organic Law on Universities (4/2007, April 7; article 46), makes explicit reference to the right of students to receive academic attention and orientation from teachers through a tutoring and counselling system adapted to the new requirements. The new methodological approaches, which have been used to support the new teaching methodologies, give a predominant role to the processes of university counselling and tutoring. The teacherstudent dynamics becomes a unique opportunity both to perform an effective monitoring of the students' work and to promote their development (Costa, Tomás, \& Sellés, 2017).

The offer of an innovative university tutoring can be regarded as a useful tool not only for a guided development of students' learning, but also for their monitoring and coordination.

According to the report on the Bologna Process in 2012, there exist many factors which are regarded as the most frequent reasons for dropping out or making a proper monitoring of those subjects the students are studying (Curaj, Scott, Vlasceanu, \& Wilson, 2012; Lirola, \& Fernández, 2009). Among these factors, the following ones should be highlighted: wrong choice of subjects, little or no adequate training or lack of involvement and commitment of students. Nevertheless, this report emphasizes the fact that several countries provide a series of services and tools to their university students. These services and tools have helped develop the systems of academic counselling, tutoring and psychological assistance for students, promoting, in this sense, the processes of academic adaptation of such students.

(C) 2018 by the authors; licensee Modestum Ltd., UK. This article is an open access article distributed under the terms and conditions of the Creative Commons Attribution License (http://creativecommons.org/licenses/by/4.0/). $\square$ dpjorge@ull.es (*Correspondence) $\square$ fbarraga@ull.edu.es $\square$ jgutierb@ull.edu.es $\square$ fmcastro@ull.edu.es 


\section{Contribution of this paper to the literature}

- The results of this research will open up new paths in the processes of university tutoring.

- The evidences found point to the need to improve the processes of counselling, tutoring and monitoring of students. In this sense, the m-learning tools are becoming essential tools to compensate the effects and gaps derived from face-to-face academic tutoring performed in a traditional way at the university.

- This experience is a first approach to future research lines in the field of academic tutoring and counseling as regards university students.

Moreover, these reports state that the use of these student support services is essential to improve the processes of learning development and performance in the tasks and autonomous work of the student (Papadakis \& Kalogiannakis, 2017)

Therefore, we consider it essential to know the effect of the use of this synchronous communication tool (WhatsApp) in the processes of academic monitoring, counselling and tutoring of university students. The widespread use of WhatsApp, as a communication tool (more than $70 \%$ of Spanish people's mobile phones) ${ }^{1}$, justifies its choice compared to other lesser-known tools such as Telegram.

\section{LITERATURE REVIEW}

In recent years, and more concretely after the implementation of the European Higher Education Area (EHEA), academic tutoring has taken an important role related to the academic promotion and success of university students, to such an extent that tutoring is presently considered as an educational quality indicator due to its relation with the improvement of results and students' satisfaction.

A fact that has been highlighted is absenteeism. It is a predictor of dropout among students. Some researches, such as that conducted by Fuente, Carpeño, Castejón, Martínez, and Lorente (2017), focus on the relation among the students' grades and absenteeism and the processes of counselling and tutoring in the university. According to these authors, students' tutoring and counselling in the university are essential to continue attending university and to get academic achievements. Studies such as that of Rodríguez, Hernández, Alonso, and Díez (2003) and Rodríguez (2013), propose different improvements as regard the processes of tutoring. They particularly emphasize the improvements related to teaching innovation and training as regards alternative spaces and tools for all students as Papadakis, Kalogiannakis and Zaranis (2017), and Papadakis, Kalogiannakis, and Zaranis (2018). However we think it is very important for the tutoring and counselling process in university students. They also propose the need to use strategies to allow greater flexibility in the present tutoring framework to introduce new guidelines and scenarios for student-teacher interaction and communication. According to this proposal, there must be a change in the teacher's role with the aim of promoting new scenarios in the students' counselling and tutoring (Romero-Cerezo, Zurita-Ortega, and Zurita-Molina, (2010). This model becomes possible with the use of alternative tools and procedures which promote active and permanent learnings based on continuous counselling.

In this sense, university tutoring has to be adopted as a process of assistance, guidance and counselling to students. This process must be based on the personalisation of learnings and on the development of personal, academic and professional competences developed throughout their studies from a dynamic perspective and taking into account their personal and professional project (Lobato \& Echeverría, 2004).

As it has been observed, university counselling and tutoring are crucial in higher education (Lobato \& Guerra, 2014; Neville, 2007). Both the technological development and globalization of education have promoted the development of technological tools and applications which have generated new concerns as regards the approaches, models and methods of the traditional academic tutoring. In this sense, authors such as Savickas et al. $(2009$, p.3) have suggested the reformulation of the academic tutoring and counselling approach, proposing the model "Life designing", based on the "urgent activation of development interventions of the individual, of the incorporation of counselling in their process of reflection and resolution of problems occurring in the personal, professional and occupational evolution". This modern conception emphasizes two basic elements: the individual's commitment in the creation of his/her own life project through a regular and systematic reflection (Di Fabio \& Bernaud, 2010) and the necessary counselling on the part of professionals in different modalities and contexts (Paul, 2009). This approach makes us reflect upon the use of alternative tools to face-to-face academic tutoring, which promote the continuous monitoring and contact with students, what we call "full tutoring".

Recent studies such as those carried out by García (2014), Sanz (2014), Albaladejo et al. (2015), Gómez et al. (2015), Garzozi (2015), Johnston et al. (2015), Farmer, Liu, and Dotson (2016), Gende (2016), Jaén and Ramalho (2016), Rodríguez-Martínez, Valerio-Ureña, Cárdenas-Anaya, and Herrera-Murillo, (2016), de Mera and Cayuso

${ }^{1}$ El Mundo: http:/ /www.elmundo.es/economia/2015/02/25/54ece95cca47414b488b456f.html 
(2017), Podpliota, (2017), Suárez (2017), Wasserman and Zwebner (2017), Castro-León, del Castillo-Olivares, PérezJorge, and Leiva-Olivenza (2018), Hrastinski, Cleveland-Innes, and Stenbom (2018), Samaie, Mansouri, and Qaracholloo (2018) show the positive effects of the use of WhatsApp as a synchronous communication tool within the framework of higher education, we are convinced that the use of this tool promotes the model which we have called "full tutoring". The objective of this research is to evaluate the effects of the use of this communication tool in the academic monitoring, counselling and tutoring of university students in the Faculty of Education at the University of La Laguna. We consider that the results of this study will open up new paths in the processes of university tutoring.

University entrance and admission imply for new students a novel situation. In just over a month, students pass from the organizational working model of post-compulsory secondary education (High School) to a university working model. The transition from High School to University needs an adaptation process to university education. It is a critical stage which needs priority attention to avoid failure and drop out situations. This change produces in the student fear, anxiety, uncertainty, confusion, disorientation difficulties (academic, curriculum, interpersonal, administrative, informative difficulties among others). The lack of resources and strategies to make academic decisions which promote in students a greater autonomy and independence, requires processes and strategies which let them give meaning to their actions to ensure the improvement of the effectiveness in decision making processes. In many cases, these students suffer from a physical and affective uprooting and have to leave their homes and live in places which are close to the university settings, leaving their families and friends behind.

These aspects are significant conditioning factors to achieve students' adaptation to University and may negatively influence not only their motivation and level of satisfaction but also their learning and academic performance.

\section{OBJECTIVES OF THE STUDY}

To know to what extent the use of WhatsApp promotes:

1. Participation and collaboration of students in specific subjects or in situations related to academic orientation processes.

2. The updated use of academic information.

3. The autonomous work of students, solving in real time academic doubts to promote the continuation of students' work.

4. The recollection of relevant situations which are related to academic training and tutoring and counselling orientation.

5. Participation in spaces for collaboration among students to clarify, update or share information among all members of the learning community.

6. The use of this tool for tutoring and counselling as an alternative to face to face tutoring.

7. The processes of academic counselling and tutoring, both from the students' and teachers' points of view.

\section{METHODOLOGY}

Some basic principles related to guiding intervention are found in the basis of this proposal in educational innovation. Such principles are based on prevention, through the student's continuous clarification and counselling (active learning), as a teaching-learning strategy with a design and implementation focused on the promotion of continuous participation and analysis through the permanent communication and interaction process which this tool offers: motivation. Individual and group difficulties in the training process will be able to be detected, allowing us to reinforce and motivate the students, leading to the improvement of their expectations and chance of success through the use of an informal language which lets improve the participants' motivational climate.

A double support and counselling system will be developed. On the one hand, peer tutoring: the students from the different groups clarify and discuss specific problematic situations related to academic issues or tutoring. On the other hand, teachers' educational support and counselling will be the responsible for promoting the active and continuous use of this tool, asking questions, making comments, giving data or interesting links, etc.

The sample of participants in this research was made up of 120 students who were incorporated to the WhatsApp groups which were created for this study. See distribution in Table 1. 
Table 1. Profiles of respondents

\begin{tabular}{|c|c|c|c|c|}
\hline Subject & Degree & Age & Gender & Participants \\
\hline $\begin{array}{c}\text { Strategies for specific } \\
\text { attention to student } \\
\text { diversity }\end{array}$ & $\begin{array}{l}\text { Master in Educational } \\
\text { Psychology Intervention } \\
\text { in contexts of formal and } \\
\text { informal education. }\end{array}$ & $\begin{array}{c}\text { Average age: } 24,3 \text { years } \\
\text { old }\end{array}$ & $\begin{array}{c}\text { Male (M): } 4 \\
\text { Female (F): } 12\end{array}$ & $\begin{array}{c}\text { Control: } \\
M=2 \\
F=6 \\
\text { Experimental: } \\
M=2 \\
F=6\end{array}$ \\
\hline $\begin{array}{l}\text { Information and } \\
\text { Communication } \\
\text { Technologies }\end{array}$ & $\begin{array}{l}\text { Degree in Early } \\
\text { Childhood Education }\end{array}$ & $\begin{array}{c}\text { Average age: } 18,9 \text { years } \\
\text { old }\end{array}$ & $\begin{array}{l}\text { Male: } 6 \\
\text { Female: } 40\end{array}$ & $\begin{array}{c}M=3 \\
F=20 \\
\text { Experimental: } \\
M=3 \\
F=20\end{array}$ \\
\hline $\begin{array}{l}\text { Inclusive activities for } \\
\text { students: present } \\
\text { educational challenges }\end{array}$ & Degree in Pedagogy & $\begin{array}{c}\text { Average age: } 20,3 \text { years } \\
\text { old }\end{array}$ & $\begin{array}{l}\text { Male: } 8 \\
\text { Female: } 50\end{array}$ & $\begin{array}{c}M=4 \\
F=25 \\
\text { Experimental: } \\
M=4 \\
F=25\end{array}$ \\
\hline
\end{tabular}

Table 2. Related to the effects on the improvement of university students' competences

\section{Competences related}

to academic work and Transversal competences or skills performance

1. TEAMWORK. Capacity to actively participate to achieve a common objective subordinating individual interests to the objectives of the team.

1.-Planning, organization 2. ADAPTABILITY TO CHANGE. Capacity to adapt to changes, modifying, if it is necessary, the and time management students' behaviour to achieve certain objectives, new information or adjust to changes in the environment, changes in the external environment or changes related to the requirements related to 2.-Active learning (attendance and participation in the learning community, decision-making, the use of WhatsApp as a tool

for academic tutoring changes in the way of acting. their academic work.

3. CONTINUOUS LEARNING. It is the capacity to find and share useful information to solve certain situations.

4.-COMMITMENT AND UNDERSTANDING OF THE ORGANIZATION. Capacity to consider as his or her own the objectives of the organization.

and counselling) changes in the way of acting. 6. ORGANIZATION AND PLANNING. Capacity to effectively determine the objectives and priorities of their tasks/ areas/ projects, providing action, deadlines and those resources required. 7. SUCCESS ORIENTATION/ RESULTS. Obtaining positive results.

The process and development of this study involved the following series of tasks:

1. A training seminar on strategies to promote learning through information and communication technologies (ICT), (forum dynamics, chats and synchronous communication spaces), paying special attention to effective communication processes and to the acquisition of necessary competences to apply the development of virtual communities as an innovative tool in the educational context.

2. Creation of learning communities to promote WhatsApp as a tool to improve academic monitoring, counselling and tutoring of each tutor who participated in this research.

Taking into account those data collected by teachers related to the students' participation, the following results were analyzed according to their effect on: a) Competences related to academic work and performance b) Transversal competences (Table 2). The effect of the use of WhatsApp on the improvement of such competences has let us evaluate the advantages of the use of this tool to improve learning, tutoring, monitoring and counselling processes of the students who participated in this research.

An ad hoc questionnaire was used to evaluate the development of both those competences related to academic work and performance and those transversal competences through the use of an m-learning tool based on peer tutoring (Herrera \& Enrique, 2008). Although this is a test which has been concretely developed for this research, we applied the "Use and Satisfaction Questionnaire on University Tutoring (CUSTU)" created by Clares, Cusó, and Juárez (2016) made up by different areas which try to collect the students' opinions as regards the different aspects of university tutoring and the use of WhatsApp as a tool to develop both general and transversal competences.

A scale was designed taking into account a questionnaire with Likert-type questions with five levels of answers. Each answer was valued punctuating from 1 (the lowest level of agreement) to 5 (the highest level of agreement). 
Table 3. Reliability analysis of the questionnaire: subscales, number of items and value of $\alpha$ Cronbach

\begin{tabular}{lcc}
\hline Subscales & $\mathbf{N}^{\circ}$ items & $\boldsymbol{\alpha}$ Cronbach \\
\hline 1. Teamwork. & 6 & 0.801 \\
\hline 2. Adaptability to change. & 4 & 0.813 \\
\hline 3. Continuous learning. & 3 & 0.711 \\
\hline 4. Commitment and understanding of the organization. & 4 & 0.764 \\
\hline 6. Management capacity. & 4 & 0.798 \\
\hline 7. Organization and planning. & 5 & 0.761 \\
\hline 8. Success orientation/ results & 5 & 0.807 \\
\hline Total & $\mathbf{3 1}$ & $\mathbf{0 . 8 6 4}$ \\
\hline
\end{tabular}

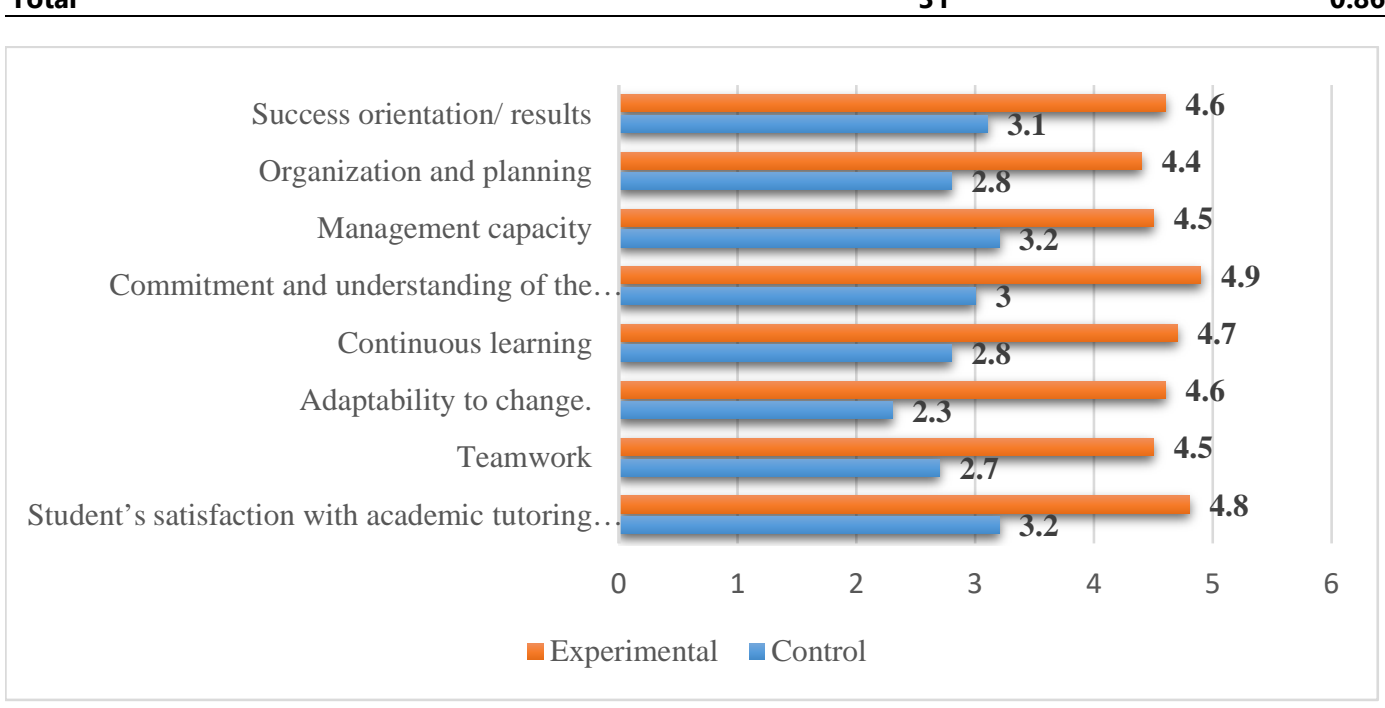

Figure 1. Average scores for each factor (Control/Experimental)

Taking into account the scores given by the participants to each of the items, an analysis of the main components was performed through the VARIMAX rotation procedure. The index KMO of sampling adequateness obtained an acceptable value of 0.864 , and enabled us to proceed with factorization (Bartlett test of sphericity; $\chi 2=30.1,1253 \mathrm{gl}$, $p<0.000)$. We decided to opt for 7 factors or components which explained a $58.7 \%$ of the variance.

\section{FINDINGS OF THE STUDY}

In order to analyze the results obtained, we compare the average scores (T Test) in the control and experimental group according to dimensional contrast. Furthermore, the results obtained were compared taking into account the different degrees (one-way Anova). Figure 1 shows the average scores obtained in each group and in each of the dimensions analyzed.

Our results revealed differences as regards each of the factors included in the analysis.

General satisfaction with academic tutoring and counselling; there were differences between the control and the experimental group. Students who did not participate in the experience of academic tutoring and counselling through m-learning (WhatsApp) $\left(\bar{\chi}_{1}=3.2\right)$ showed a worse perception and satisfaction of this factor than those students who were supervised and tutored through WhatsApp $\left(\bar{\chi}_{2}=4.8\right) .(F(1,2)=0.507 ; \mathrm{p}=0.002)$.

As regards the remaining dimensions, the results were the following ones: teamwork $\left[\left(\bar{\chi}_{1}=2.7 ; \bar{\chi}_{2}=4.5 ; \mathrm{F}(1,2)=\right.\right.$ $0.187 ; \mathrm{p}=0.003)] ;$ adaptability to change $\left[\left(\bar{\chi}_{1}=2.3 ; \bar{\chi}_{2}=4.6 ; \mathrm{F}(1,2)=0.237 ; \mathrm{p}=0.001\right)\right]$; continuous learning $\left[\left(\bar{\chi}_{1}=2.8 ; \bar{\chi}_{2}=\right.\right.$ 4.7; $\mathrm{F}(1,2)=0.569 ; \mathrm{p}=0.005)]$; commitment and understanding of the organization $\left[\left(\bar{\chi}_{1}=3.0 ; \bar{\chi}_{2}=4.9 ; \mathrm{F}(1,2)=0.402\right.\right.$; $\mathrm{p}=0.002)]$; management capacity $\left[\left(\bar{\chi}_{1}=3.2 ; \bar{\chi}_{2}=4.5 ; \mathrm{F}(1,2)=2.673 ; \mathrm{p}=0.000\right)\right] ;$ organization and planning $\left[\left(\bar{\chi}_{1}=2.8 ; \bar{\chi}_{2}=4.4 ;\right.\right.$ $\mathrm{F}(1,2)=2.319 ; \mathrm{p}=0.001)] ;$ success orientation/ results $\left[\left(\bar{\chi}_{1}=3.1 ; \bar{\chi}_{2}=4.6 ; \mathrm{F}(1,2)=7.249 ; \mathrm{p}=0.003\right)\right]$. Significant differences were observed for each of the dimensions analyzed in this study. This fact revealed an improvement of the results in the experimental group compared to the control group which did not work with the m-learning tool based on peer tutoring.

\section{CONCLUSION}

The use of WhatsApp (m-learning) as a tool to develop the processes of university counselling and tutoring has proven to be effective. In general, students have had easy access to any kind of information, anywhere at any time. 
This has let them participate actively in the planning and development of tasks, being informed of those changes and modifications performed during the academic course and having updated and useful information. Moreover, they have been able to be actively involved in learning tasks and improve their level of motivation and involvement in the academic work. As opposed to the control group, the students have expressed their satisfaction and the advantages of this tutoring method as compared to other traditional methods.

The flexibility that the use of WhatsApp offers and its permanent availability make it a useful resource for academic tutoring and learning achievement. The introduction of a system of academic tutoring and counselling, such as the one we have put into practice in this research experience, opens the way for the development of other possibilities which let complement the students' academic training. In this sense, an autonomous learning, in which it is not necessary to attend face-to-face counselling sessions to acquire and develop competences and knowledge, is developed.

\section{ACKNOWLEDGEMENTS}

We are thankful to University of La Laguna for providing institutional support through the innovation project to make this research possible in the 2016-2017 public announcement.

https:/ / drive.google.com/file/d/0B_NWxPjo5wSpYTcxVUUxM2RUbG8/view

\section{REFERENCES}

Albaladejo, C. B., Aznar, A. B., Cabañero, M. C., Pérez, N. F., Pastor, E. I., Carbonell, S. J., ... Gómez, B. R. (2015). Educación y asesoramiento del alumno para el correcto uso de las tutorías. In Investigación y Propuestas Innovadoras de Redes UA para la Mejora Docente (pp. 204-218). Instituto de Ciencias de la Educación.

Castro-León, F. M., del Castillo-Olivares, J. M., Pérez-Jorge, D., \& Leiva-Olivenza, J. J. (2018). Videoconference in Academic Tutoring: A Case Study. Asian Social Science, 14(2), 49-56. https:// doi.org/10.5539/ass.v14n2p49

Clares, P., Cusó, J., \& Juárez, M. (2016). Las TICs y el entorno virtual para la tutoría universitaria. Educación XX1, 19(1), 287-310.

Costa, J. A. G., Tomás, M. T. C., \& Sellés, P. M. (2017). ¿Cómo valoran los estudiantes los procesos de tutoría universitaria? In Book of Abstracts.

Curaj, A., Scott, P., Vlasceanu, L., \& Wilson, L. (Eds.). (2012). European higher education at the crossroads: between the Bologna process and national reforms. Springer Science \& Business Media.

de Mera, D. S., \& Cayuso, P. L. (2017). La adicción al Whatsapp en adolescentes y sus implicaciones en las habilidades sociales/The WhatsApp Acciction in Adolescents and its Implication on Social Skills. Tendencias pedagógicas, 29,121-134.

Di Fabio, A., \& Bernaud, J.-L. (2010). Un nouveau paradigme pour la construction de la carrière au 21e siècle : bienvenu !, L'orientation scolaire et professionnelle, 39(1),111-118.

Farmer, M. Y., Liu, A., \& Dotson, M. (2016). Mobile Phone Applications (WhatsApp) Facilitate Communication Among Student Health Volunteers in Kenya. Journal of Adolescent Health, 58(2), 54-55. https:// doi.org/10.1016/j.jadohealth.2015.10.121

Fuente, L. C., Carpeño, A., Castejón, Á., Martínez, M., \& Lorente, L. (2017, October). Absentismo y Abandono en primer curso de grado en la universidad Politécnica de Madrid: Decálogo de prácticas para su reducción. In Congresos CLABES.

García, D. (2014). M-learning. Posibilidades educativas de Whatsapp. Retrieved from https:/ / www.youtube.com/ watch?v=vMtU4ZdW264

Garzozi, R. (2015). Experiencia del uso de las TIC en la tutoría del trabajo final de titulación de la Maestría de Auditoría Integral. Conferencias LACLO, 6, 351. Retrieved from http://brie.org/pub/index.php/teste/article/view/5818/4108

Gende, I. M. (2016). Creación de comunidad y comunicación mediante el uso de Whatsapp en la elaboración online de Trabajos Fin de Máster de Formación de Profesorado. DIM: Didáctica, Innovación y Multimedia, 33, 1-8.

Gómez, B. R., Albaladejo, C. B., Cabañero, M. C., Pérez, N. F., Pastor, E. I., Carbonell, S. J., ... Aznar, A. B. (2015). La adquisición de competencias y su evaluación a través de la participación del alumno. In XIII Jornadas de Redes de Investigación en Docencia Universitaria: Nuevas estrategias organizativas y metodológicas en la formación universitaria para responder a la necesidad de adaptación y cambio (pp.2560-2574). Instituto de Ciencias de la Educación. Alicante, España.

Herrera, L., \& Enrique, C. (2008). Proyectos de Innovación en Tutorías en la Universidad de Granada: Análisis de los instrumentos empleados. Profesorado. Revista de Currículum y Formación del Profesorado, 12(2), 1-18. 
Hrastinski, S., Cleveland-Innes, M., \& Stenbom, S. (2018). Tutoring online tutors: Using digital badges to encourage the development of online tutoring skills. British Journal of Educational Technology, 49(1), 127-136. https://doi.org/10.1111/bjet.12525

Jaén, M. D. M., \& Ramalho, A. P. (2016). Las TIC como apoyo a la tutoría en la educación infantil. Una propuesta para la colaboración. Dedica. Revista de Educação e Humanidades, 9, 55-74.

Johnston, M. J., King, D., Arora, S., Behar, N., Athanasiou, T., Sevdalis, N., \& Darzi, A. (2015). Smartphones let surgeons know WhatsApp: an analysis of communication in emergency surgical teams. The American Journal of Surgery, 209(1), 45-51. https:/ / doi.org/10.1016/j.amjsurg.2014.08.030

Lirola, M., \& Fernández, E. (2009). La tutoría universitaria en el modelo de la convergencia europea. In L. Gómez (2009). Propuestas de diseño, desarrollo e innovaciones curriculares y metodológicas en el EEES, (pp. 451-466) Marfil; Alicante: Universidad de Alicante.

Lobato, C., \& Echevarría, B. (2004). Tutorías y sistemas de apoyo a los estudiantes. In AA.VV. Pedagogía Universitaria: hacia un espacio de aprendizaje compartido, (pp. 299-301). Bilbao: editorial ICE de la Universidad de Deusto y Ediciones Mensajero.

Lobato, C., \& Guerra, N. (2014). Las Tutorías universitarias en el contexto europeo. Orientación y sociedad, 14, 00-00. Retrieved from http:/ / www.scielo.org.ar/scielo.php?script=sci_arttext\&pid=S1851-88932014000100003

Neville, L. (2007). The personal tutor's handbook. Basingstoke. Palgrave.

Papadakis, S., \& Kalogiannakis, M. (2017). Mobile educational applications for children: what educators and parents need to know? International Journal of Mobile Learning and Organisation, 11(3), 256-277.

Papadakis, S., Kalogiannakis, M., \& Zaranis, N. (2017). Designing and creating an educational app rubric for preschool teachers. Education and Information Technologies, 22(6), 3147-3165. https://doi.org/10.1504/IJMLO.2017.085338

Papadakis, S., Kalogiannakis, M., \& Zaranis, N. (2018). Educational apps from the Android Google Play for Greek preschoolers: A systematic review. Computers $\mathcal{E}$ Education, 116, 139-160. https:/ / doi.org/10.1016/j.compedu.2017.09.007

Paul, M. (2009). Accompagnement. Recherche et formation, 62, 129-139.

Podpliota, S. (2017). Tutoring Support as an Important Component of the Educational Process in the Context of the Development of Information and Communication Technology. Ukrainian Journal of Educational Studies and Information Technology, 5(3), 84-91. Retrieved from http:/ / ojs.mdpu.org.ua/index.php/itse

Rodríguez, E. D. (2013). Tutoría universitaria: propuestas didácticas de competencia tutorial. REDU: Revista de Docencia Universitaria, 11(2), 195-220.

Rodríguez, R., Hernández J., Alonso A. M., \& Díez, E. (2003). El absentismo en la Universidad: resultados de una encuesta sobre motivos que señalan los estudiantes para no asistir a clase. Aula Abierta, 82, 117-145.

Rodríguez-Martínez, M. C., Valerio-Ureña, G., Cárdenas-Anaya, C. A., \& Herrera-Murillo, D. J. (2016). Percepción y realidad del uso de WhatsApp en estudiantes universitarios de ciencias de la salud. FEM: Revista de la Fundación Educación Médica, 19(3), 118-124.

Romero-Cerezo, C., Zurita-Ortega, F., \& Zurita-Molina, F. (2010). Autonomía y orientación en el Espacio Europeo de Educación Superior mediante el portafolio y la tutoría. Estudios sobre Educación, 12, 261-282

Samaie, M., Mansouri Nejad, A., \& Qaracholloo, M. (2018). An inquiry into the efficiency of WhatsApp for self-and peer-assessments of oral language proficiency. British Journal of Educational Technology, 49(1), 111-126. https:/ / doi.org/10.1111/bjet.12519

Sanz, J. J. (2014). Whatsapp: potencialidad educativa versus dependencia y adicción. Retrieved from http:/ / dim.pangea.org/revistaDIM30/docs/OC30whatsapp.pdf

Savickas, M. L., Nota, L., Rossier, J., Dauwalder, J. P., Duarte, M. E., Guichard, J., Soresi, S., Van Esbroeck, R., \& van Vianen, A. E. M. (2009). Life designing: A paradigm for career construction in the 21st century. Journal of Vocational Behavior, 75(3), 239-250. https:/ / doi.org/10.1016/j.jvb.2009.04.004

Suárez, B. (2017). El WhatsApp como herramienta de apoyo a la tutoría. REDU. Revista de Docencia Universitaria 15(2), 193-210.

Wasserman, E., \& Zwebner, Y. (2017). Communication between Teachers and Parents using the WhatsApp Application. International Journal of Learning, Teaching and Educational Research, 16(12), 1-12. https://doi.org/10.26803/ijlter.16.12.1

\section{http://www.ejmste.com}

